


\section{About IJMA [last updated October, $\left.1^{\text {st }}, 2021\right]$}

$\checkmark$ International Journal of Medical Arts is the Official Journal of the Damietta Faculty of Medicine, AlAzhar University, Egypt

$\checkmark$ It is an International, Open Access, Double-blind, Peer-reviewed Journal

$\checkmark$ Published four times a year

$\checkmark$ The First Issue was published in July 2019

$\checkmark$ Published under the following license: Creative Commons Attribution-ShareAlike 4.0 International Public License (CC BY-SA 4.0). It had updated from the Creative Commons license [CC BY] in volume 2, Issue 4, October 2020 About IJMA

$\checkmark$ The Egyptian Knowledge Bank hosts the web site of IJMA

$\checkmark$ The Egyptian Knowledge Bank supports IJMA

$\checkmark$ IJMA follows the regulations of the International Committee of Medical Journal Editors

$\checkmark$ IJMA is indexed in the "Directory of Open Access Journals" [15 January 2021].

$\checkmark$ IJMA is indexed in J-Gate [29-6-2021]

$\checkmark$ IJMA is a member of the International Society of Managing and Technical Editors

$\checkmark$ Listed in "Index Copernicus", "Publons", "Academic resource index [ResearchBib]" "Electronics journal library", "Eurasian Scientific Journal Index", "WorldCat" Superstar Journal Database, and "Citefactor"

$\checkmark$ IJMA introduced to the search engine [BASE] through DOAJ

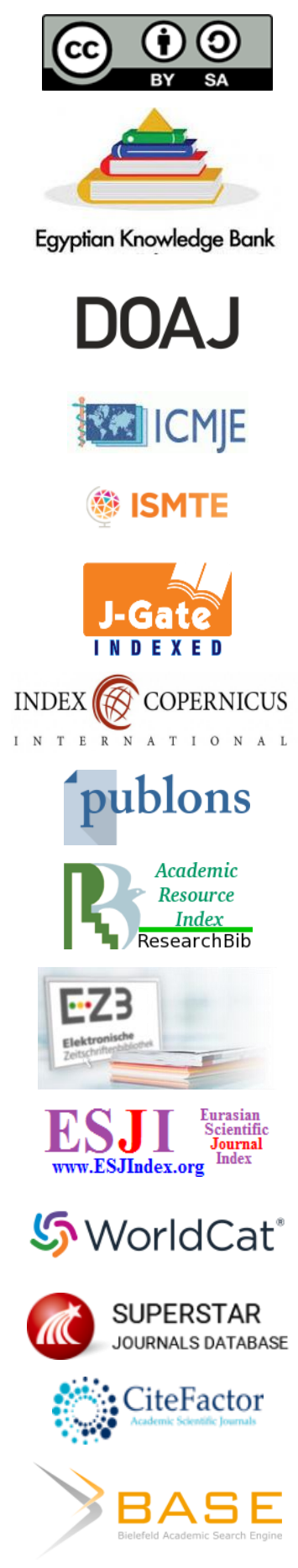




$\begin{gathered}\text { Available online at Journal Website } \\ \text { https://ijma.journals.ekb.eg/ } \\ \text { Main subject [Pediatrics] }\end{gathered}$
Masis

Original Article

\title{
Prevalence and Risk Factors of Hepatitis C Virus Infection among High- risk Egyptian Children
}

\author{
Mahmoud Hodeib [1], Alzhraa Fahmy [2], Gamal Taha [1], Mostafa Sheemy [3], Manar Ali [4] \\ 1 Department of Pediatrics, Faculty of Medicine, Beni-Suef University, Egypt \\ ${ }^{2}$ Department of Tropical Medicine and Infectious Diseases, Faculty of Medicine, Beni-Suef University, Egypt \\ ${ }^{3}$ Department of Medical Microbiology and Immunology, Faculty of Medicine, Beni-Suef University, Egypt \\ ${ }^{4}$ Department of Pediatrics, Beni-Suef General Hospital, Egypt \\ Corresponding author: Alzhraa Fahmy \\ Email: alzhraamohamed@med.bsu.edu.eg
}

Submission date: May 19, 2021; Acceptance date: September 01, 2021

DOI: 10.21608/IJMA.2021.76789.1314

\section{ABSTRACT}

Background: Hepatitis C virus [HCV] infection is a global health problem. Children with certain risk factors are at high risk of infection.

Objective: The present study aimed to evaluate the prevalence of HCV among high-risk Egyptian children.

Methods: The study included 1357 children aged 3-15 years with risk factors of HCV including receiving blood products, hemodialysis, previous surgical intervention, insulin therapy and positive family history. They were subjected to careful history taking, thorough clinical examination and routine laboratory investigations. All children were tested for HCV antibodies using commercial 4th generation enzymelinked immunosorbent assay [ELISA] kits. Those with positive results were further assessed using polymerase chain reaction [PCR].

Results: Among the studied patients, there were 89 children [6.6\%] with positive HCV Ab and 73 children [5.4 \%] with positive PCR test for HCV. Using multivariate logistic regression, significant predictors of HCV infection in the studied children were blood transfusion [OR: 1.23, Cl: 0.019-13.4], Intravenous [IV] injection [OR: 10.962, Cl: 1.937-62.026] and previous operation [OR: 3.12, Cl: 1.046-31.6].

Conclusion: HCV infection is highly prevalent among high-risk children. Blood transfusion, IV injection and exposure to surgery are independent risk factors for infection in this population.

Keywords: Hepatitis C infection; Perinatal transmission; Hepatitis screening

This is an open-access article registered under the Creative Commons, ShareAlike 4.0 International license [CC BY-SA 4.0] [https://creativecommons.org/licenses/by-sa/4.0/legalcode.

Citation: Hodeib M, Fahmy A, Taha G, Sheemy M, Ali M. Prevalence and Risk Factors of Hepatitis C Virus Infection among High-risk Egyptian Children. IJMA 2021; 3 [4] October-December: 1792-1796. [DOI: 10.21608/IJMA.2021.76789.1314].

* Main subject and any subcategories have been classified according to the research topic 


\section{INTRODUCTION}

Hepatitis C virus [HCV] infection is a major medical challenge affecting around 200 million people worldwide including $\sim 11$ million children [1]. HCV is a member of the Flaviviridae family of RNA-containing viruses. The primary immune response to HCV is mounted by cytotoxic $\mathrm{T}$ lymphocytes. Unfortunately, this process fails to eradicate infection in most people [2].

Unfortunately, in contrast to older people, the published estimates of HCV burden among children are misleading due to lack of universal screening ${ }^{[3]}$. Perinatal transmission can also affect an estimated $5 \%$ of babies born to mothers with HCV infection [4]. Children exposed to blood transfusion or hemodialysis are at high risk of $\mathrm{HCV}$ infection. Use of injected drugs is another important epidemiologic risk factor ${ }^{[5]}$. It is noted that the prevalence of $\mathrm{HCV}$ is higher among children treated for malignancy and those who had undergone surgical procedures ${ }^{[6]}$.

More than three quarters of the children are symptomless and cirrhosis and hepatocellular carcinoma are rare [7]. Spontaneous viral clearance can commonly occur in young children but its rate declines as age advances [8]. If a child or adolescent is suspected of having $\mathrm{HCV}$, initial testing is to screen with antibodies made by the body against HCV [9]. In all children, use of direct acting antivirals in now recommended. Treatment protocol depends on child age and HCV genotype with the aim of complete viral clearance ${ }^{[10,11]}$.

\section{AIM OF THE WORK}

The present study aimed to establish a risk-based selective screening of hepatitis $C$ in children in Beni-Suef Governorate in Egypt.

\section{PATIENTS AND METHODS}

This cross-sectional study was conducted at Pediatric Departments of the University Faculty of Medicine and the General Hospitals in Beni-Suef during the period from June, 2018 through February, 2020. The study protocol conforms to the ethical guidelines of the 1975 Declaration of Helsinki [6 $6^{\text {th }}$ revision, 2008] reflected in a priori approval by the institution's human research committee. Informed consent was obtained from the legal guardians of all participants. The sample size was calculated using $G$ Power 3.1 [Kiel University, Germany]. Using $\alpha$ error probability of 0.05 and study power of $95 \%$, the minimum required sample size is 806 considering the reported prevalence of HCV among similar population in a previous study [5.8\%].
The study recruited all children aged 3-15 years with risk factors of $\mathrm{HCV}$ including receiving blood products, hemodialysis, previous surgical intervention, insulin therapy and positive family history. Children were excluded if they had history of liver disease.

The study included 1357 children. They were subjected to careful history taking, thorough clinical examination. All children were tested for HCV antibodies using commercial $4^{\text {th }}$ generation ELISA kits [OraSure Technologies Inc., Bethlehem, USA]. Those with positive results were further assessed using polymerase chain reaction [PCR]. All children with positive HCV on PCR examination were genotype 4. Children with HCV were treated using oral sofosbuvir $400 \mathrm{mg}$ / ledipasvir $90 \mathrm{mg}$ combination for three months. All treated children achieved sustained virologic response.

\section{Statistical analysis}

Data obtained from the present study were presented as mean and standard deviation [SD] or number and percent. Comparison between categorical variables was achieved using chi-square test while numerical variables were compared using student $t$ test. Logistic regression was used to identify predictors of binary outcome. Variable were selected to be included in regression models on the basis of previous studies and clinical judgment. Variable that were significant in univariate analysis were advanced to multivariate analysis. $P$ value less than 0.05 was considered statistically significant. All statistical calculations were processed using SPSS, 25 [IBM, Chicago, USA].

\section{RESULTS}

The present study was conducted on 1357 children with risk factors for HCV. They had and age of $7.2 \pm 3.6$ years and comprised 785 females [ $57.8 \%$ ] and 572 males [42.2\%]. Among the studied patients, there were 89 children [6.6\%] with positive HCV Ab and 73 children [5.4 $\%$ ] with positive PCR test for HCV [Table 1].

Comparison between children with HCV and children without according to PCR results is shown in [Table 2]. Factors associated with positive HCV results included blood transfusion, IV injection, previous surgery, previous hospitalization and dialysis.

Using multivariate logistic regression, significant predictors of HCV infection in the studied children were blood transfusion [OR: 1.23, Cl: 0.019-13.4], IV injection [OR: 10.962, Cl: 1.937-62.026] and previous operation [OR: 3.12, Cl: 1.046-31.6] [Table 3]. 


\begin{tabular}{|c|c|c|c|c|}
\hline & $\begin{array}{l}\text { All children } \\
N=1357\end{array}$ & $\begin{array}{l}\text { HCV +ve } \\
n=73\end{array}$ & HCV-ve $n=1284$ & P value \\
\hline Age [years] mean \pm SD & $7.2 \pm 3.6$ & $6.9 \pm 3.5$ & $7.3 \pm 2.7$ & 0.2 \\
\hline \multicolumn{5}{|l|}{ Sex $n[\%]$} \\
\hline Female & $785[57.8]$ & 41 [56.2] & $744[58.0]$ & \multirow[t]{2}{*}{0.85} \\
\hline Male & $572[42.2]$ & $32[43.8]$ & $540[42.0]$ & \\
\hline \multicolumn{5}{|c|}{ Socioeconomic class $\mathrm{n}[\%]$} \\
\hline Low & $5[0.4]$ & - & $5[0.4]$ & \multirow[t]{3}{*}{0.82} \\
\hline Moderate & $1350[99.5]$ & $73[100.0]$ & $1277[99.4]$ & \\
\hline High & $2[0.1]$ & - & $2[0.2]$ & \\
\hline \multicolumn{5}{|l|}{ Residence } \\
\hline Rural & $1252[92.3]$ & 68 [93.2] & 1184 [92.2] & \multirow[t]{2}{*}{0.77} \\
\hline Urban & $105[7.7]$ & $5[6.8]$ & $100[7.8]$ & \\
\hline \multicolumn{5}{|c|}{ Reported risk factors $\mathrm{n}[\%]$} \\
\hline Blood transfusion & $385[28.4]$ & 49 [67.1] & $336[29.9]$ & $<0.001$ \\
\hline Family history & $96[7.1]$ & $6[8.2]$ & $90[7.0]$ & 0.7 \\
\hline Injections & $906[66.8]$ & $73[100.0]$ & $833[64.9]$ & $<0.001$ \\
\hline Previous operation & $113[8.3]$ & $15[20.5]$ & $98[7.6]$ & $<0.001$ \\
\hline Hospitalization & $906[66.8]$ & $73[100.0]$ & $833[64.8]$ & $<0.001$ \\
\hline Circumcision & $572[42.2]$ & $32[43.8]$ & $540[42]$ & 0.79 \\
\hline Ear piercing & $767[56.5]$ & $25[34.2]$ & $742[57.8]$ & 0.55 \\
\hline Dialysis & $16[1.2]$ & 16 [21.9] & - & $<0.001$ \\
\hline Insulin injection & $30[2.2]$ & $3[4.1]$ & $27[2.1]$ & 0.26 \\
\hline
\end{tabular}

Table [2]: Comparison between children with HCV and children without regarding the basic data

\begin{tabular}{|c|c|c|c|}
\hline & $\begin{array}{c}\mathrm{HCV}+\mathrm{ve} \\
n=73\end{array}$ & $\begin{array}{c}\text { HCV -ve } \\
n=1284\end{array}$ & P value \\
\hline Age [years] mean \pm SD & $6.9 \pm 3.5$ & $7.3 \pm 2.7$ & 0.2 \\
\hline \multicolumn{4}{|l|}{$\operatorname{Sex} n[\%]$} \\
\hline Female & $41[56.2]$ & 744 [58.0] & \multirow[t]{2}{*}{0.85} \\
\hline Male & 32 [43.8] & 540 [42.0] & \\
\hline \multicolumn{4}{|c|}{ Socioeconomic class $\mathrm{n}$ [\%] } \\
\hline Low & - & $5[0.4]$ & \multirow[t]{3}{*}{0.82} \\
\hline Moderate & $73[100.0]$ & $1277[99.4]$ & \\
\hline High & - & $2[0.2]$ & \\
\hline \multicolumn{4}{|l|}{ Residence $\mathrm{n}[\%]$} \\
\hline Rural & 68 [93.2] & 1184 [92.2] & \multirow[t]{2}{*}{0.77} \\
\hline Urban & $5[6.8]$ & $100[7.8]$ & \\
\hline \multicolumn{4}{|c|}{ Reported risk factors $\mathrm{n}[\%]$} \\
\hline Blood transfusion & 49 [67.1] & $385[29.9]$ & $<0.001$ \\
\hline Family history & 6 [8.2] & $90[7.0]$ & 0.7 \\
\hline Injection & $73[100.0]$ & $833[64.9]$ & $<0.001$ \\
\hline Previous operation & $15[20.5]$ & 98 [7.6] & $<0.001$ \\
\hline Hospitalization & $73[100.0]$ & $833[64.8]$ & $<0.001$ \\
\hline Circumcision & $32[43.8]$ & $540[42]$ & 0.79 \\
\hline Ear piercing & $25[34.2]$ & $742[57.8]$ & 0.55 \\
\hline Dialysis & 16 [21.9] & - & $<0.001$ \\
\hline Insulin injection & $3[4.1]$ & $27[2.1]$ & 0.26 \\
\hline
\end{tabular}




\begin{tabular}{|c|c|c|c|c|}
\hline & \multirow[t]{2}{*}{ P-value } & \multirow[t]{2}{*}{ OR } & \multicolumn{2}{|c|}{$95 \% \mathrm{Cl}$} \\
\hline & & & Lower & Upper \\
\hline Blood transfusion & $<0.001$ & 1.23 & 0.019 & 13.4 \\
\hline Positive Family History & 0.914 & 1.084 & 0.252 & 4.650 \\
\hline Injection & 0.007 & 10.962 & 1.937 & 62.026 \\
\hline Previous operation & $<0.001$ & 3.121 & 1.046 & 31.60 \\
\hline Hospitalization & 0.992 & 0.000 & 0.000 & - \\
\hline Circumcision & 0.446 & 0.529 & 0.103 & 2.715 \\
\hline Ear piercing & 0.326 & 0.426 & 0.078 & 2.337 \\
\hline Dialysis & 0.998 & 0.000 & 0.000 & - \\
\hline Insulin injection & 0.299 & 0.310 & 0.034 & 2.825 \\
\hline
\end{tabular}

\section{DISCUSSION}

Hepatitis $C$ is an important health challenge worldwide. Egypt is the most affected country with hepatitis $C$. The estimated sero-prevalence of hepatitis C in Egypt was $14.7 \%$ in 2009 and $10 \%$ in 2015. Egypt has recently developed a national strategy for prevention, diagnosis, and treatment of hepatitis $C$ with the goal of achieving a national chronic infection prevalence of less than $2 \%$ by 2025 [12]. The prevalence of hepatitis $C$ among Egyptian children is in general lower than that of the general population. As of 2015 estimates, the seroprevalence of hepatitis C in Egyptian children 1-14 years old was $0.4 \%$, and that confirmed by PCR was $0.2 \%{ }^{[13] \text {. }}$

There are several risk factors associated with higher prevalence of hepatitis $\mathrm{C}$. In this cross-sectional study, we screened 1357 children aged 3-15 years with certain risk factors for the presence of hepatitis $C$. Among the studied patients, there were 89 children [6.6\%] with positive HCV $\mathrm{Ab}$ and 73 children [5.4\%] with positive PCR test for HCV. These figures are comparable to that reported by another Egyptian study conducted on healthy children including high and normal risk subjects in the pre-DAA era where 5.8 $\%$ of the studied 500 children were anti-HCV positive and $4.4 \%$ were positive for HCV PCR test [14]. In other countries, however, the seroprevalence of HCV among children was notably lower. In Mexico, it was $2.0 \%$ [15], $0.24 \%$ in Brazil [16]. The prevalence of HCV reported by the present study is also higher than the global estimate of $0.13 \%$ reported by a recent modeling study [17].

In the present study, factors associated with positive HCV results included blood transfusion, IV injection, previous surgery, previous hospitalization, and dialysis in univariate analysis. However, using multivariate logistic regression, significant predictors of HCV infection in the studied children were blood transfusion, IV injection and previous operation.
Previous studies consistently showed that blood transfusion and IV injection are significant risk factor of hepatitis $C$ in children [14, 18]. Also, the study of Abd ElWahab, Abdel Maksoud [19] noted a significant association between history of previous surgery and HCV infection in children.

Nonetheless, other studies identified a significant association between other risk factors and HCV infection in children. These factors included family history of HVC infection [14, 18], circumcision [14, 19], ear piercing [18] and hemodialysis [20].

\section{CONCLUSION}

In conclusion, HCV infection in children still constitutes a significant challenge particularly in the high-risk groups even in the DAA era. Efforts should continue to accomplish the national target of clearing Egypt from HCV by 2030.

Financial and Non-financial Relationships and Activities of Interest

None

\section{REFERENCES}

1. Thursz M, Fontanet A. HCV transmission in industrialized countries and resource-constrained areas. Nat Rev Gastroenterol Hepatol. 2014 Jan;11(1):28-35. DOI: 10.1038/nrgastro.2013.179.

2. Indolfi G, Azzari C, Resti M. Perinatal transmission of hepatitis C virus. J Pediatr. 2013 Dec; 163(6):15491552.e1. DOI: 10.1016/j.jpeds.2013.06.077.

3. Espinosa C, Jhaveri R, Barritt AS 4th. Unique Challenges of Hepatitis $C$ in Infants, Children, and Adolescents. Clin Ther. 2018 Aug;40(8):1299-1307. DOI: 10.1016/j.clinthera.2018.07.010. 
4. Poordad F, McCone J Jr, Bacon BR, Bruno S, Manns MP, Sulkowski MS, et al. Boceprevir for untreated chronic HCV genotype 1 infection. N Engl J Med. 2011; 364 (13):1195-206. DOI: 10.1056/NEJMoa1010494.

5. Yeung LT, Roberts EA. Current issues in the management of paediatric viral hepatitis. Liver Int. 2010; 30 (1):5-18. DOI: 10.1111/j.1478-3231.2009. 02145.x.

6. Squires JE, Balistreri WF. Hepatitis C virus infection in children and adolescents. Hepatol Commun. $2017 \mathrm{Mar}$ 23;1(2):87-98. DOI: 10.1002/hep4.1028.

7. Bacon BR, Gordon SC, Lawitz E, Marcellin P, Vierling $\mathrm{JM}$, Zeuzem $\mathrm{S}$, et al. Boceprevir for previously treated chronic HCV genotype 1 infection. N Engl J Med. 2011 Mar;364(13):1207-17. DOI: 10.1056/NEJMoa1009482.

8. Karnsakul W, Schwarz KB. Management of Hepatitis C Infection in children in the era of Direct-acting Antiviral Agents. J Viral Hepat. 2019 Sep;26(9):1034-1039. DOI: 10.1111/jvh.13113.

9. Jonas MM, Balistreri W, Gonzalez-Peralta RP, Haber $B$, Lobritto $S$, Mohan $P$, et al. Pegylated interferon for chronic hepatitis $C$ in children affects growth and body composition: results from the pediatric study of hepatitis C (PEDS-C) trial. Hepatology. 2012 Aug;56(2):523-31. DOI: 10.1002/hep.25690.

10. Wirth $S$, Rosenthal $P$, Gonzalez-Peralta RP, Jonas $\mathrm{MM}$, Balistreri WF, Lin $\mathrm{CH}$, et al. Sofosbuvir and ribavirin in adolescents 12-17 years old with hepatitis $C$ virus genotype 2 or 3 infection. Hepatology. 2017 Oct;66(4):1102-1110. DOI: 10.1002/hep.29278.

11. Indolfi G, Serranti D, Resti M. Direct-acting antivirals for children and adolescents with chronic hepatitis $C$. Lancet Child Adolesc Health. 2018 Apr;2(4):298-304. DOI: $10.1016 /$ S2352-4642(18)30037-3.

12. Kouyoumjian SP, Chemaitelly $\mathrm{H}$, Abu-Raddad LJ. Characterizing hepatitis $\mathrm{C}$ virus epidemiology in Egypt: systematic reviews, meta-analyses, and metaregressions. Sci Rep. 2018 Jan 26;8(1):1661. DOI: 10.1038/s41598-017-17936-4.
13. Kandeel A, Genedy M, El-Refai S, Funk AL, Fontanet $A$, Talaat $M$. The prevalence of hepatitis $C$ virus infection in Egypt 2015: implications for future policy on prevention and treatment. Liver Int. 2017 Jan;37(1):4553. DOI: $10.1111 /$ iv. 13186.

14. Barakat SH, El-Bashir N. Hepatitis C virus infection among healthy Egyptian children: prevalence and risk factors. J Viral Hepat. $2011 \mathrm{Nov} ; 18(11): 779-84$. DOI: 10.1111/j.1365-2893.2010.01381.x.

15. Escobedo-Meléndez G, Fierro NA, Roman $S$, Maldonado-González M, Zepeda-Carrillo E, Panduro A. Prevalence of hepatitis $A, B$ and $C$ serological markers in children from western Mexico. Ann Hepatol. 2012 Mar-Apr;11(2):194-201. PMID: 22345336.

16. Villar LM, Amado LA, de Almeida AJ, de Paula VS, Lewis-Ximenez $L L$, Lampe $E$. Low prevalence of hepatitis $B$ and $C$ virus markers among children and adolescents. Biomed Res Int. 2014;2014:324638. DOI: $10.1155 / 2014 / 324638$.

17. Schmelzer J, Dugan E, Blach S, Coleman S, Cai Z, DePaola M, et al. Global prevalence of hepatitis $C$ virus in children in 2018: a modelling study. Lancet Gastroenterol Hepatol. 2020 Apr;5(4):374-392. DOI: 10.1016/S2468-1253(19)30385-1.

18. Trickey A, May MT, Davies C, Qureshi H, Hamid S, Mahmood $\mathrm{H}$, et al. Importance and Contribution of Community, Social, and Healthcare Risk Factors for Hepatitis C Infection in Pakistan. Am J Trop Med Hyg. 2017;97(6):1920-1928. DOI: 10.4269/ajtmh.17-0019.

19. Abd El-Wahab EW, Abdel Maksoud A, Shatat HZ, Kotkat AM. Risky exposures and national estimate of HCV seroprevalence among school children in urban Egypt. Virusdisease. 2016 Dec;27(4):351-356. DOI: 10.1007/s13337-016-0345-5.

20. Youssef DM, Abdo $H$, Alakhras A, Adham T, Mohamoud AH. Hepatitis $C$ in children with chronic kidney disease: A single-center, Egypt. Saudi J Kidney Dis Transpl. 2017 Jan-Feb;28(1):102-106. DOI: 10.4103/1319-2442.198161. 


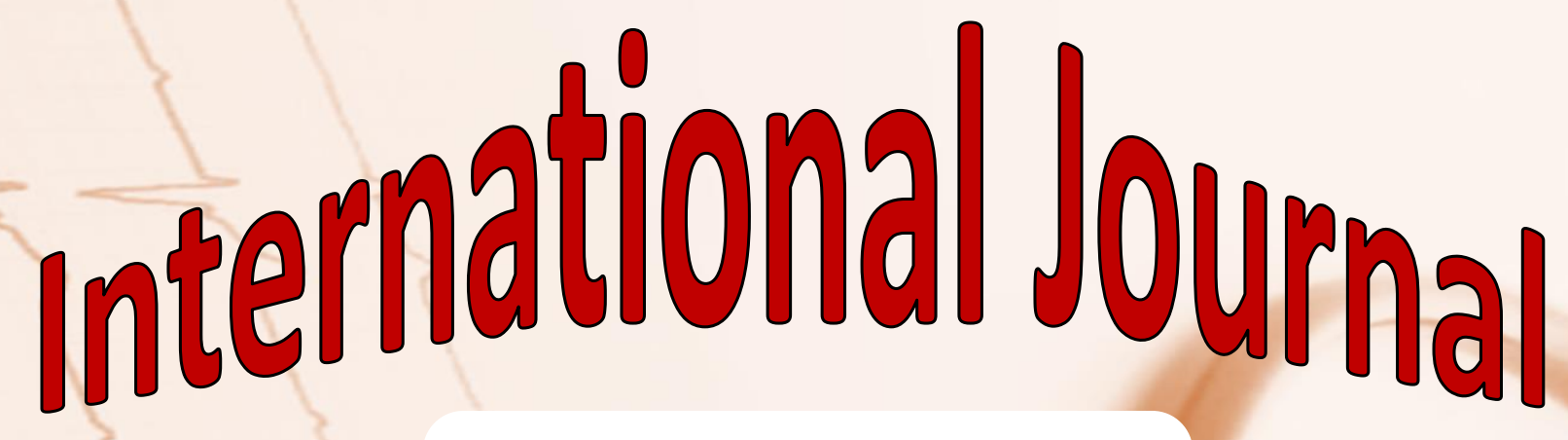

https://ijma.journals.ekb.eg/ Print ISSN: 2636-4174 Online ISSN: 2682-3780

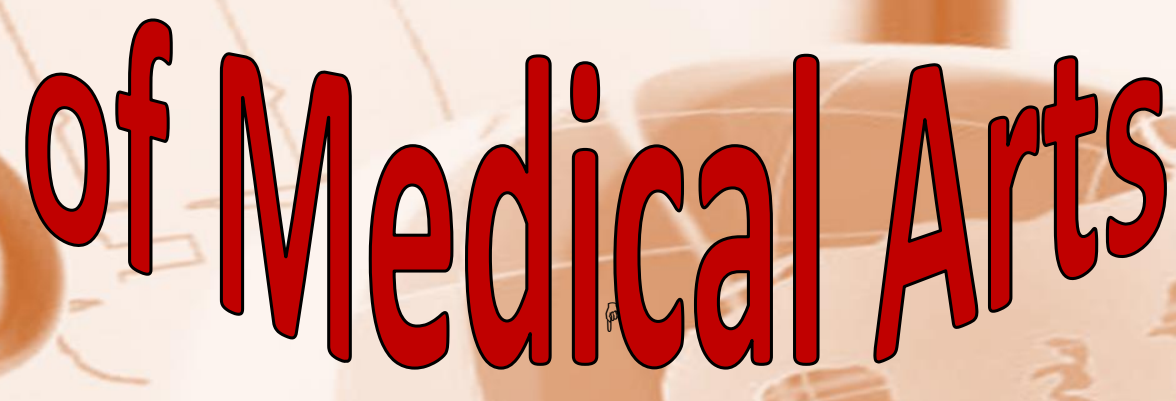

